\title{
Modeling ecosystem disruptive algal blooms: positive feedback mechanisms
}

\author{
William G. Sunda*, Kyle W. Shertzer \\ CCFHR, National Oceanographic and Atmospheric Administration, 101 Pivers Island Road, Beaufort, North Carolina 28516, USA
}

\begin{abstract}
Harmful blooms of algae that disrupt and degrade ecosystems (ecosystem disruptive algal blooms, EDABs) are occurring with increasing frequency with eutrophication and other adverse anthropogenic alterations of coastal systems. EDAB events have been hypothesized to be caused by positive feedback interactions involving differential growth of competing algal species, low grazing mortality rates on EDAB species, and resulting decreases in nutrient inputs from grazer-mediated nutrient cycling as the EDAB event progresses. Here we develop a nutrientphytoplankton-zooplankton model to test the conceptual positive feedback hypothesis. In this model we compete the low-nutrient adapted brown tide EDAB species Aureoumbra lagunensis and 2 high-nutrient-adapted diatoms (Thalassiosira pseudonana and T. weissflogii) using published data for growth rate versus limiting nutrient (ammonium) concentration. The model results support the positive feedback hypothesis for EDAB formation, and verify that bloom formation requires low grazing rates on the EDAB species. The model predicts that because of the positive feedback, the harmful bloom should persist once formed. The model further shows that the likelihood and biomass intensity of an EDAB event is increased by greater residence time of water in a coastal system and that increased nutrient supply increases its severity. Our results demonstrate that EDAB events do not simply involve a direct stimulation of growth of harmful species by increased nutrients, but rather involve complex interactions among the growth of competing algal species, differential grazing on those species, and changes in nutrient cycling that are directly linked to algal grazing.
\end{abstract}

KEY WORDS: EDABs - Plankton models - Positive feedback - Nutrients - Phytoplankton · Zooplankton $\cdot$ Brown tide $\cdot$ Diatoms

\section{INTRODUCTION}

Phytoplankton represent the base of the marine food web and are responsible for roughly half of the earth's photosynthesis (Field et al. 1998). Consequently, they support world fisheries (Ryther 1969) and play a pivotal role in oceanic carbon cycling and in the regulation of atmospheric $\mathrm{CO}_{2}$ and global greenhouse warming (Martin 1990, Sigman \& Boyle 2000). Certain groups of phytoplankton have an additional influence on climate through the production of the gas dimethylsulfide, which facilitates cloud formation (Charlson et al. 1987). Many of these same phytoplankton (coccolithophores) precipitate calcium carbonate, which regulates the alkalinity of seawater and its ability to sequester $\mathrm{CO}_{2}$ (Dymond \& Lyle 1985).

In contrast to these beneficial functions, a number of species have formed massive blooms in recent decades in coastal waters that have disrupted marine ecosystems and harmed coastal economies and human health (Hoagland et al. 2002, Glibert et al. 2005). Such harmful algal blooms have occurred with increasing frequency in recent years with eutrophication and other anthropogenic alterations of coastal ecosystems (Cloern 2001). Many of these harmful blooms severely alter or degrade ecosystem function, and have been referred to as ecosystem disruptive 
algal blooms (EDABs) (Sunda et al. 2006). These blooms are often caused by toxic or unpalatable species that decrease grazing rates by planktonic and benthic herbivores, and thereby disrupt the transfer of nutrients and energy to higher trophic levels and decrease nutrient cycling. EDAB species include brown-tide-forming pelagophytes (Aureoumbra lagunensis and Aureococcus anophagefferens), greentide-forming species (the trebouxiophyte Nannochloris atomus and the eustigmatophyte Nannochloropsis gaditana), toxic-bloom-forming haptophytes (Chrysochromulina polylepis and Prymnesium parvum), and some toxic-bloom-forming cyanobacteria (e.g. Nodularia spumigena) and dinoflagellates (Sunda et al. 2006).

Both algal nutrient availability and herbivore grazing are known to influence the dynamics of EDAB events and algal blooms in general (Irigoien et al. 2005, Buskey 2008). Potential interactions between these 2 factors have also been noted because the nutritional status of phytoplankton prey (i.e. their nutrient:carbon ratios) can influence the growth and nutrient recycling rates of zooplankton (Sterner \& Elser 2002, Mitra \& Flynn 2005). Sunda et al. (2006) presented a novel conceptual model for the development of EDABs based on positive feedback interactions among competition of algal species for limiting nutrients, differential herbivore grazing, and grazerlinked nutrient regeneration. The proposed positive feedback resulted from a reduction of grazing rates on EDAB species caused by toxicity or unpalatability, which promoted the proliferation of these algae. The decreased grazing rates also lowered grazer-mediated recycling of nutrients and thereby decreased nutrient availability. Because many EDAB species are well adapted to nutrient-stressed environments and many exhibit increased toxicity under nutrient limitation, positive feedbacks should occur, which were hypothesized to promote the development of harmful blooms and their adverse effects on the ecosystem (Sunda et al. 2006).

In the present paper we develop a numerical nutrient-phytoplankton-zooplankton (NPZ) model to test one of the positive feedback hypotheses of Sunda et al. (2006) for the development of EDAB events (Hypothesis 1) in which the toxin content or palatability of the EDAB alga does not change with nutrient limitation. To test the validity of the proposed mechanism, we 'competed' the Texas (USA) brown tide EDAB species Aureoumbra lagunensis (A.l.), against 2 estuarine diatoms, including a smaller species Thalassiosira pseudonana (T.p.) ( 4.5 $\mu \mathrm{m}$ diameter) roughly the same size as A.l., and a larger species
Thalassiosira weissflogii (T.w.) ( 10.5 $\mu$ m diameter). A.l. was chosen for this modeling effort because it formed a massive long-lasting EDAB event in the Laguna Madre, Texas (USA) from 1990 to 1997 that was associated with low grazing rates by zooplankton and benthic invertebrates (Buskey \& Stockwell 1993, Buskey \& Hyatt 1995, Buskey et al. 2001).

Laboratory experiments have verified that A.l. is toxic, poorly grazed, and/or poorly assimilated by grazing organisms, including microzooplankton, copepods, and the larvae of a dominant benthic polychaete (Buskey \& Hyatt 1995, Ward et al. 2000). It possesses a thick polysaccharide sheath which appears to deter algal grazers by fouling the cilia that generate feeding currents (Liu \& Buskey 2000) and by allowing the cells to resist digestion in the guts of zooplankton (Bersano et al. 2002). The 2 diatoms (T.p. and T.w.) were chosen for the model because they are high-nutrient-adapted species that grow well at high-nutrient concentrations (Sunda \& Hardison 2007); such diatoms were hypothesized to form pre-blooms that drew nutrients to low concentrations, setting the stage for EDAB events (Sunda et al. 2006). The small diatom T.p. has a higher maximum growth rate than the larger species T.w. and outcompetes the larger diatom at all ammonium concentrations; but it should also be grazed at a higher rate than T.w., and thus should have higher grazing mortality losses (Sunda \& Hardison 2010).

These 3 species were also chosen because of the availability of recently published data on relationships among nutrient (ammonium) concentration, ammonium uptake rate, cellular nitrogen:carbon $(\mathrm{N}: \mathrm{C})$ ratios, and specific growth rate (Sunda \& Hardison $2007,2010)$. These data were used for the construction of models relating the concentration of a limiting nutrient (ammonium) to algal ammonium uptake rates, cellular $\mathrm{N}: \mathrm{C}$ ratios, and specific growth rate in the 2 diatoms T.p. and T.w. (Sunda \& Hardison 2007, Sunda et al. 2009). A similar approach was then used here to model data for ammonium limitation of Aureoumbra lagunensis published previously (Sunda \& Hardison 2007, 2010). These growth models allowed us to quantify growth competition for the limiting nutrient ammonium among the 3 species.

Nitrogen was chosen as the limiting nutrient in our models because it is the primary limiting nutrient in estuarine, coastal, and stratified oceanic waters (Ryther \& Dunstan 1971, Sanders et al. 1987, Moore et al. 2008). Thus, nitrogen uptake and utilization are critical factors regulating the competitive success of marine algal species. More importantly, there is evidence that the Texas brown tide bloom of A.l. was 
growth-limited by nitrogen, based on cellular ratios of $\mathrm{N}: \mathrm{C}$ and chlorophyll $a: \mathrm{C}$, and chl a cell ${ }^{-1}$ measured during the bloom (DeYoe \& Suttle 1994). Ammonium was chosen as the limiting form of nitrogen for several reasons. First, it is the preferred nitrogen source among nitrogen species (ammonium, nitrate, nitrite, urea, and various other organic nitrogen species) as most other chemical species (with the exception of amino acids) must first be converted to $\mathrm{NH}_{4}{ }^{+}$before they are assimilated into proteins and other nitrogencontaining biomolecules. This ammonium conversion entails the investment of additional energy (adenosine triphosphate), enzymatic machinery, or photosynthetic reducing equivalents (NADPH), and, thus, ammonium use is energetically more efficient than utilization of most other nitrogen species. Consequently, $\mathrm{NH}_{4}{ }^{+}$is frequently the primary limiting inorganic $\mathrm{N}$ species in $\mathrm{N}$-limited marine waters (Harrison et al. 1996). Second, ammonium is the most important inorganic form of regenerated nitrogen (Dugdale \& Goering 1967, Verity 1985) and, thus, is an essential component of NPZ models that include grazermediated nitrogen regeneration. Third, in culture experiments with an A.l. isolate, this species was incapable of utilizing nitrate, highlighting its growth dependence on ammonium and other reduced, regenerated nitrogen forms (DeYoe \& Suttle 1994, Muhlstein \& Villareal 2007). However, the main practical reason for choosing ammonium as the limiting nutrient is the recent availability (noted above) of critical data for relationships among ammonium concentration, nitrogen uptake rate, cellular nitrogen, and specific growth rate for A.l. and some other EDAB species, and for competing algal species (Sunda \& Hardison 2007, 2010). Due to analytical difficulties, no equivalent data are available for any other nitrogen substrate.

Another important process included in our NPZ model is species-specific grazing by zooplankton, which differentially removes specific algal species from the system and, thus, along with differential rates of growth, controls the species composition of the algal community. Grazing supports the growth and reproduction of the grazer and has another critical function: it facilitates the regeneration (recycling) of nutrients through excretion. Thus, it is essential for resupplying the nutrient (ammonium) pool, especially during periods of low external nutrient supply to the system.

In the present study we were interested in using our model to investigate the role of differential grazing among algal species in promoting blooms of individual algal species. We were especially interested in

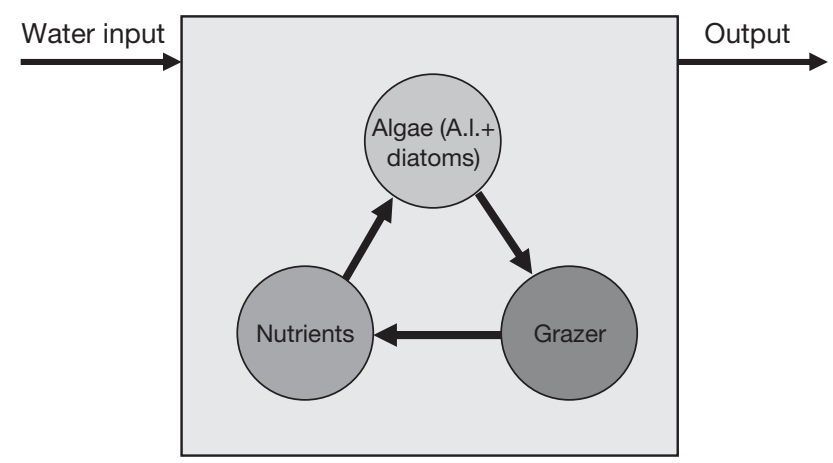

Fig. 1. Conceptual model of the nutrient-phytoplanktonzooplankton system

examining the effect of low grazing rates on EDAB species in promoting the occurrence and persistence of ecosystem disruptive algal blooms via the positive feedback interactions proposed by Sunda et al. (2006). We also used our model to examine the effect of the water residence time and the nutrient concentration in the inflowing water, as both factors influence nutrient input rates and the concentration of growth-limiting nutrients.

\section{METHODS}

\section{Model structure}

The conceptual ecosystem model (Fig. 1) assumes a single well-mixed water body in which water enters and exits at the same rate, such as in a chemostat or an idealized coastal lagoon. The inflowing water contains nutrients but no algae or grazers. Nitrogen in the form of ammonium is assumed to be the sole limiting algal nutrient $(N)$. A simple biological community is comprised of 3 competing phytoplankton $\left(P_{i}\right)$ speciesthe brown tide species Aureoumbra lagunensis $(i=1)$ and 2 diatoms, Thalassiosira pseudonana $(i=2)$ and $T$. weissflogii $(i=3)$ - as well as a single zooplankton grazer $(Z)$ that feeds at differential rates on the 3 algal species. We quantified this conceptual system using a stoichiometric NPZ model. Here, we highlight several of the model's key features and assumptions (a full model description and parameter values are given in Supplement 1 at www.int-res.com/articles/suppl/ m447p031_supp.pdf).

The NPZ model is governed by a system of differential equations:

$$
\begin{gathered}
\frac{\mathrm{d} N}{\mathrm{~d} t}=\delta\left(N_{\mathrm{in}}-N\right)-\sum_{i} V_{i} P_{i}+\left(R_{\mathrm{I}}+R_{\mathrm{E}}+R_{\mathrm{m}}\right) Z \\
\frac{\mathrm{d} Q_{i}}{\mathrm{~d} t}=V_{i}-\mu_{i} Q_{i}
\end{gathered}
$$




$$
\begin{aligned}
\frac{\mathrm{d} P_{i}}{\mathrm{~d} t} & =\left(\mu_{i}-\delta\right) P_{i}-I_{i} Z \\
\frac{\mathrm{d} Z}{\mathrm{~d} t} & =\left(\mu_{\mathrm{z}}-m-\delta\right) Z
\end{aligned}
$$

where $Q_{i}$ is the $\mathrm{N}$ :C ratio of phytoplankton species $i_{i}$ $V_{i}$ is the nitrogen uptake rate of phytoplankton species $i$ normalized to cell carbon; $R_{\mathrm{I}}, R_{\mathrm{E}}$, and $R_{\mathrm{m}}$ are the nutrient recycling rates (normalized to zooplankton carbon) associated with zooplankton defecation of feces, excretion of excess nitrogen, and mortality, respectively; $\mu_{i}$ is the specific growth rate of phytoplankton species $i_{i} \mu_{\mathrm{z}}$ is the specific growth rate of the zooplankton; $m$ is the specific mortality rate of the zooplankton; and $I_{i}$ is the carbon-based specific ingestion rate of phytoplankton $i$ by zooplankton. The ammonium input rate equals the concentration in the inflowing water $\left(N_{\text {in }}\right)$ times the dilution rate $(\delta)$ of the water body (equals 1/residence time), while the ammonium washout rate equals the ammonium concentration in the water body times the dilution rate. The total ammonium uptake rate by the algae equals the sum of the uptake rates of the 3 algal species, while the net growth rate of each $\left(\mathrm{d} P_{i} / \mathrm{d} t_{i}\right.$ mol algal carbon $\left.\mathrm{l}^{-1} \mathrm{~d}^{-1}\right)$ equals the specific growth rate $\left(\mu_{i} \mathrm{~d}^{-1}\right)$ times the carbon-based biomass of each species $\left(\mathrm{mol} \mathrm{C}^{-1}\right)$, minus rates of loss from washout and grazing.

\section{Nutrient uptake and growth of phytoplankton}

Ammonium uptake rates for T.w. and T.p. were modeled using a modified Michaelis-Menten equation (Supplement 1; Sunda et al. 2009). Uptake rates for both species increased approximately linearly with nutrient concentration until saturating at a maximum rate. For that reason and because of data limitations, we assumed a piecewise linear model for the uptake rate of A.l. (Supplement 2 at www.int-res.com/articles/ suppl/m447p031_supp.pdf). For all 3 phytoplankton species, specific growth rates $\left(\mu_{i}\right)$ were modeled using a modified Droop equation (Supplement 1 ; Sunda et al. 2009), in which growth is a function of the cellular $\mathrm{N}: \mathrm{C}$ ratio. Parameter values for T.w. and T.p. were estimated previously by Sunda et al. (2009), and those for A.l. were estimated for this analysis using similar procedures (Supplement 2).

\section{Grazing and growth of zooplankton}

The grazer was modeled after a generic ciliate whose maximum grazing rate $\left(3.6 \mathrm{~d}^{-1}\right)$, half-saturation

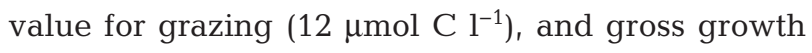
efficiency (0.39) were based on data for large ciliates ( $\mathrm{n}=5$; cell volume $6.9 \times 10^{4}$ to $21 \times 10^{4} \mu \mathrm{m}^{3}$ ) (Hansen et al. 1997). Ciliates are a dominant group of microzooplankton (Pierce \& Turner 1992), and microzooplankton are responsible for most algal grazing in estuarine and coastal waters (Calbet \& Landry 2004). Grazing rates were assumed to follow a multispecies Type II functional response similar to that described by Fussmann \& Heber (2002), but modified to allow for a threshold below which grazing ceases (Gentleman et al. 2003, Tian 2006). Such thresholds, or their mathematical equivalents, have been found necessary for fitting NPZ models to marine plankton abundance data (e.g. Frost 1993, Strom et al. 2000, Leising et al. 2003). Carbon-based specific rates of ingestion $\left(I_{i}\right)$ of algal species $i$ was modeled as:

$I_{i}= \begin{cases}g_{\text {max }, i}\left(P_{T}-P_{\tau}\right)\left(P_{i} / P_{T}\right) /\left(K_{z}+P_{T}-P_{\tau}\right) & \text { if } P_{T}>P_{\tau} \\ 0 & \text { otherwise }\end{cases}$

where $g_{\max , i}$ is the maximum grazing rate of algal species $i, P_{T}=\Sigma_{j} P_{j}$ is the total algal carbon biomass (mol C l $\left.{ }^{-1}\right), P_{\tau}$ is the grazing threshold (see below), and $K_{z}$ is the half-saturation constant for grazing, which is assumed to be the same for all algal species. The $g_{\max , i}$ value for T.p., the most readily grazed species, was set at $3.6 \mathrm{~d}^{-1}$, based on published data (Hansen et al. 1997). The $g_{\max , i}$ value for the large diatom T.w. was set at $40 \%$ of that for T.p. $\left(1.44 \mathrm{~d}^{-1}\right)$ to reflect the observation that large diatoms generally have lower grazing rates than smaller species (Thingstad \& Sakshaug 1990, Kiørboe 1993). The $\mathrm{g}_{\mathrm{max}, i}$ value for A.l. was varied in our model, but was always $\leq 40 \%$ of that for T.p. to reflect the observed poor grazing rates on this species (Buskey \& Hyatt 1995).

We utilized a grazing threshold in our model $\left(P_{\tau}=\right.$

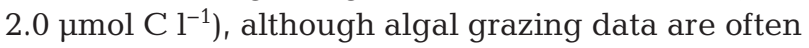
modeled as a saturation function of algal concentration with the curve passing through the origin, i.e. zero grazing rate at an algal concentration of zero (Hansen et al. 1997, Tian 2006). However, grazing data are often noisy, with little or no data at algal concentrations near zero, so whether the curve passes exactly through the origin usually cannot be readily assessed. Grazing curves derived from less noisy data at very low algal carbon biomass often have a positive $x$-intercept, with no grazing occurring until some critical algal threshold is achieved (Frost 1975, Strom 1991, Gismervik 2005, Chen et al. 2010). Furthermore, NPZ models often require the inclusion of grazing thresholds to prevent large oscillations in phytoplankton abundance, which do not conform to 
observed behavior of natural plankton communities (Frost 1993, Strom et al. 2000, Leising et al. 2003). However, the mechanistic basis of such grazing thresholds is controversial, and Strom et al. (2000) have argued that their necessary inclusion in NPZ models may be a proxy for other phenomena such as non-homogenous plankton distributions (patchiness), predation on herbivores by higher trophic levels, and complex grazing patterns in which multiple herbivores feed on mixed groups of phytoplankton.

The model accounted for stoichiometry in zooplankton by tracking both carbon- and nitrogenlimited growth $\left(\mu_{\mathrm{C}}\right.$ and $\left.\mu_{\mathrm{N}}\right)$. Carbon-limited growth was modeled as:

$$
\mu_{\mathrm{C}}=\varepsilon_{\mathrm{g}}\left(\varepsilon_{\mathrm{a}} \sum_{i} I_{i}-r\right)
$$

where $\varepsilon_{\mathrm{a}}$ is the gut assimilation efficiency for ingested carbon $(0.8), r$ is specific basal respiration rate $\left(0.1 \mathrm{~d}^{-1}\right)$, and $\varepsilon_{\mathrm{g}}$ is the growth efficiency $(0.5)$, equal to the increase in zooplankton carbon biomass divided by the net assimilated carbon available for growth (Supplement 1). Similarly, nitrogen-limited growth was modeled as:

$$
\mu_{\mathrm{N}}=\varepsilon_{\mathrm{a}} \sum_{i} I_{i} Q_{i} / Q_{\mathrm{z}}
$$

assuming a fixed $\mathrm{N}$ :C ratio in the zooplankton $\left(Q_{\mathrm{z}}\right)$ of 1:7 (Redfield et al. 1963, Sterner \& Elser 2002). Specific growth rate of zooplankton $\left(\mu_{z}\right)$ was taken to be whichever was most limiting, $\mu_{z}=\min \left(\mu_{C}, \mu_{N}\right)$.

\section{Nutrient recycling}

Grazer-mediated recycling of nitrogen (per mol carbon) stemmed from 3 sources: egestion of feces $\left(R_{\mathrm{I}}\right)$, excretion $\left(R_{\mathrm{E}}\right)$, and zooplankton mortality $\left(R_{\mathrm{m}}\right)$. Egestion equaled the nutrients ingested but not assimi-

lated, $R_{\mathrm{I}}=\left(1-\varepsilon_{\mathrm{a}}\right) \sum_{i} I_{i} Q_{i}$. Excretion occurred in the model only when zooplankton growth was carbonlimited and only when the rate of nitrogen assimilation $\left(A_{\mathrm{N}}\right)$ exceeded the need for growth $\left(G_{\mathrm{N}}\right)$. Under those conditions, unutilized nitrogen was excreted back into the nutrient pool, $R_{\mathrm{E}}=A_{\mathrm{N}}-G_{\mathrm{N}}$. In addition to consumption-related sources, the nitrogen content of dead zooplankton was recycled, $R_{\mathrm{m}}=m Q_{\mathrm{z}}$, where $m$ is the specific mortality rate. For simplicity we assumed that the nitrogen content of feces and dead zooplankton was rapidly converted to ammonium. We also assumed all excreted nitrogen was in the form of ammonium, quantitatively the most important excretion product in ciliates and other microzooplankton (Verity 1985, Caron \& Goldman 1990).

\section{Model scenarios}

We used the stoichiometric NPZ model to examine top-down and bottom-up effects in the system. For top-down effects, we first considered time-course simulations (200 to $300 \mathrm{~d}$ ) with or without a grazer in the system. When included, the grazer preyed on all algal species according to differences in their maximum grazing rates, which we varied for A.l. $\left(g_{\max , 1}=\right.$ $0.36,0.72$, or $\left.1.08 \mathrm{~d}^{-1}\right)$. We further considered asymptotic dynamics of the system across a range of $g_{\max , 1}$ values for A.l. $\left(g_{\max , 1}=0.036\right.$ to $\left.1.44 \mathrm{~d}^{-1}\right)$. In addition, we considered time-course simulations without and

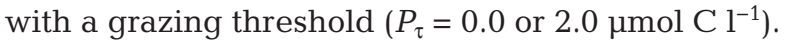

In the model, bottom-up effects were driven by the dilution rate $(\delta)$ and the concentration of nutrients in the inflowing water $\left(N_{\text {in }}\right)$. We examined time-course simulations for 2 different dilution rates $(\delta=0.05$ or $\left.0.3 \mathrm{~d}^{-1}\right)$, as well as asymptotic dynamics across a range of rates $\left(\delta \in[0.01,0.6] \mathrm{d}^{-1}\right)$. We further examined time-course simulations using 2 different concentrations of ammonium in the inflowing water $\left(N_{\text {in }}\right.$ $=4$ or $36 \mu \mathrm{M})$. In all cases, parameters not used to define a particular scenario were fixed at their base values (Supplement 1).

\section{RESULTS}

\section{Algal growth models}

Modeled relationships between specific growth rate and ammonium concentration are shown in Fig. 2A. As seen from the experimental data and the modeled growth curves, the small diatom Thalassiosira pseudonana (T.p.) outgrows the other 2 species at all ammonium levels, except at very low concentrations $(<0.01 \mu \mathrm{M})$, where it grows at rates similar to those for Aureoumbra lagunensis (A.l.). At ammonium concentrations $>0.04 \mu \mathrm{M}$, the 2 diatoms outgrow A.l., but at lower concentrations A.l. outgrows the large diatom T. weissflogii (T.w.). Thus, ammonium concentration is an important factor regulating the relative population growth of the 3 algal species.

The algal growth rate is ultimately determined by the cellular concentration of the limiting nutrient (N) (Droop 1968). Modeled Droop relationships between specific growth rate and cellular $\mathrm{N}$ : C show only a narrow 2-fold range in cellular $\mathrm{N}$ : $\mathrm{C}$ with changes in growth rate in the 2 diatoms, but a much larger 5 -fold variation in A.l. (Fig. 2B). All of the species have similar maximum $\mathrm{N}$ : C ratios of 0.13 to 0.15 at nutrient-saturated growth rates, but A.l. has an approxi- 

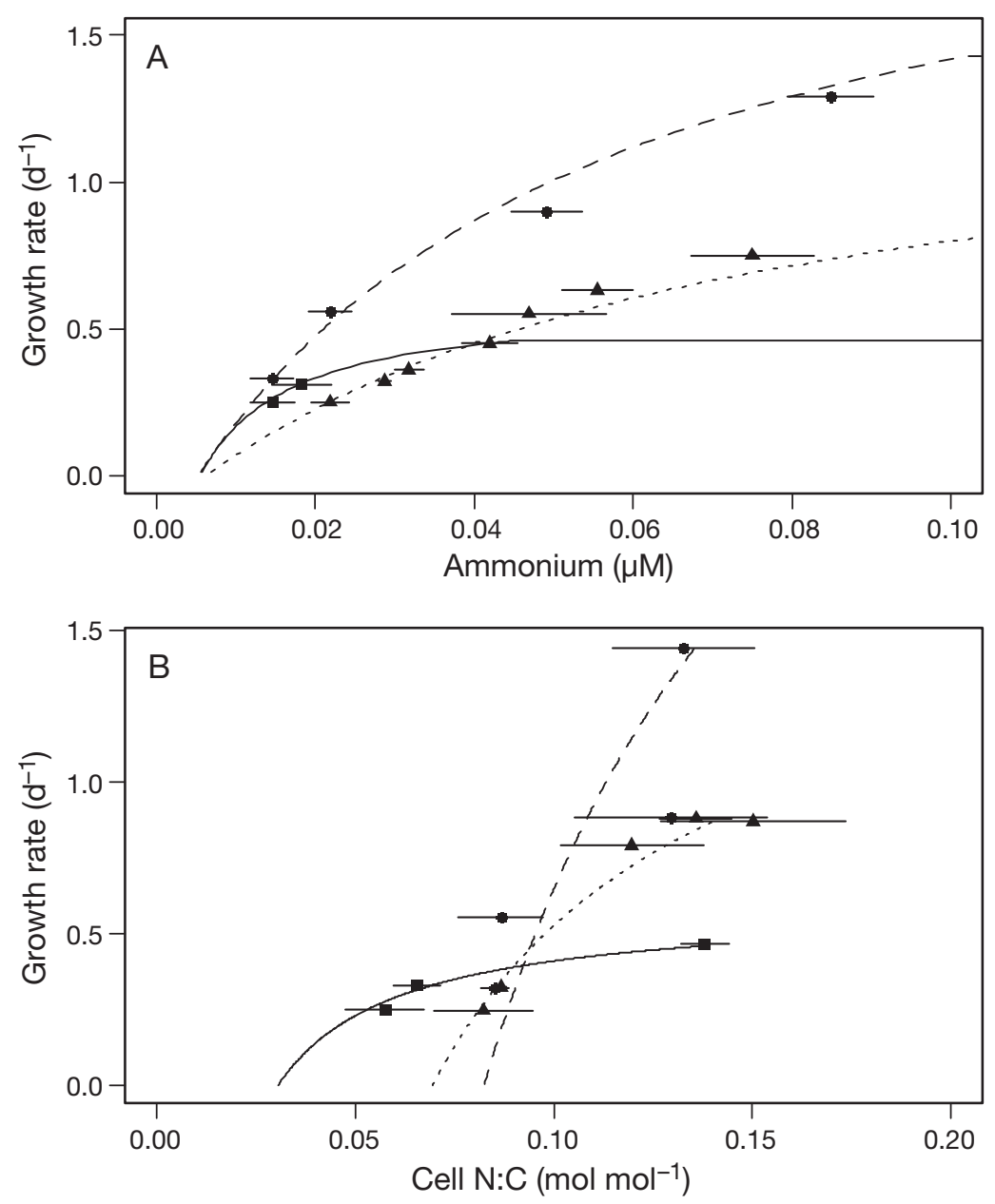

Fig. 2. (A) Steady-state growth rates of Aureoumbra lagunensis (solid line, squares), Thalassiosira pseudonana (dashed line, circles), and T. weissflogii (dotted line, triangles) as a function of ammonium concentration, and (B) specific growth rates as a function of cellular $\mathrm{N}$ : C molar ratio. Points shown are measured data (means \pm SD; Sunda \& Hardison 2007, 2010), while lines are modeled relationships. Nutrient-saturated maximum growth rates in Panel B (at N:C molar ratios of 0.13 to 0.15 ) were measured in low-density batch cultures containing $32 \mu \mathrm{M}$ added ammonium

mately 2-fold lower $\mathrm{N}$ :C ratio (i.e. a 2-fold higher $\mathrm{C}: \mathrm{N}$ ratio) than the 2 diatoms at very low growth rates.

\section{Competition models}

Top-down effects

Model runs were conducted to examine the effect of a grazer and of varying grazing rates on A.l. on the population dynamics of the algal species. In the absence of the grazer, the fast-growing diatom T.p. rapidly outgrew the other 2 species and became the overwhelmingly dominate species after several days (Fig. 3C). By contrast, in the presence of the grazer, the system showed quite complex behavior which was dependent on the maximum grazing rate on A.l. relative to those on the other 2 species, which were assigned fixed maximum specific grazing rates $\left(3.6 \mathrm{~d}^{-1}\right.$ for T.p. and $1.44 \mathrm{~d}^{-1}$ for $\mathrm{T} . \mathrm{w}$.). If the maximum grazing rate on A.l. was $>0.8 \mathrm{~d}^{-1}(>22 \%$ of that on T.p.) the system showed an initial bloom of T.p. followed by successive blooms of the large diatom T.w., as well as stable oscillations among concentrations of ammonium, the grazer, and T.w. (Fig. 3D-F). The nutrient concentrations oscillated between those that limited the growth of the algae $(<0.1 \mu \mathrm{M}$ for the 2 diatoms $)$ and high concentrations that support the maximum growth rate of all species (Fig. 3D). When maximum grazing rates on A.l. were less than about $0.75 \mathrm{~d}^{-1}$, a much different dynamic was seen (Fig. 3G to I). Here, there was still an initial bloom of the rapidly growing small diatom T.p. (Fig. 3I), which drew the nutrient concentrations down to low limiting concentrations (Fig. 3G), allowing competitive growth of the 2 slower growing species. This initial T.p. bloom was then followed by 1 or more peaks in the abundance of T.w. and slightly offset increasing peaks in A.l. abundance. There were also offset peaks in the abundance of the grazer, which allowed T.w. and A.1. to outcompete T.p. because of their low specific grazing rates. Eventually there was a 'flip' in the dynamics of the system characterized by a large increase in the abundance of A.l. and the disappearance of the competing diatoms and the grazer, and a decrease in nutrient concentrations to very low growth-limiting concentrations $(<0.01 \mu \mathrm{M})$. The lower the maximum grazing rate on A.l., the fewer were the number of preceding blooms of T.w. and the quicker the appearance of the brown tide bloom. For example, when the grazing rate on A.l. was set at $0.36 \mathrm{~d}^{-1}(10 \%$ that of T.p.), there was only 1 small peak in T.w. abundance beginning at approximately Day 30, which was coincident with a sharp rise in the abundance of the brown tide species. The abundance of T.w. and the grazer then subsided as A.l. increased to dominate the algal community (Fig. 3H,I). However, when the maximum grazing rate on A.l. was 2-fold higher $\left(0.72 \mathrm{~d}^{-1}\right)$, there were 

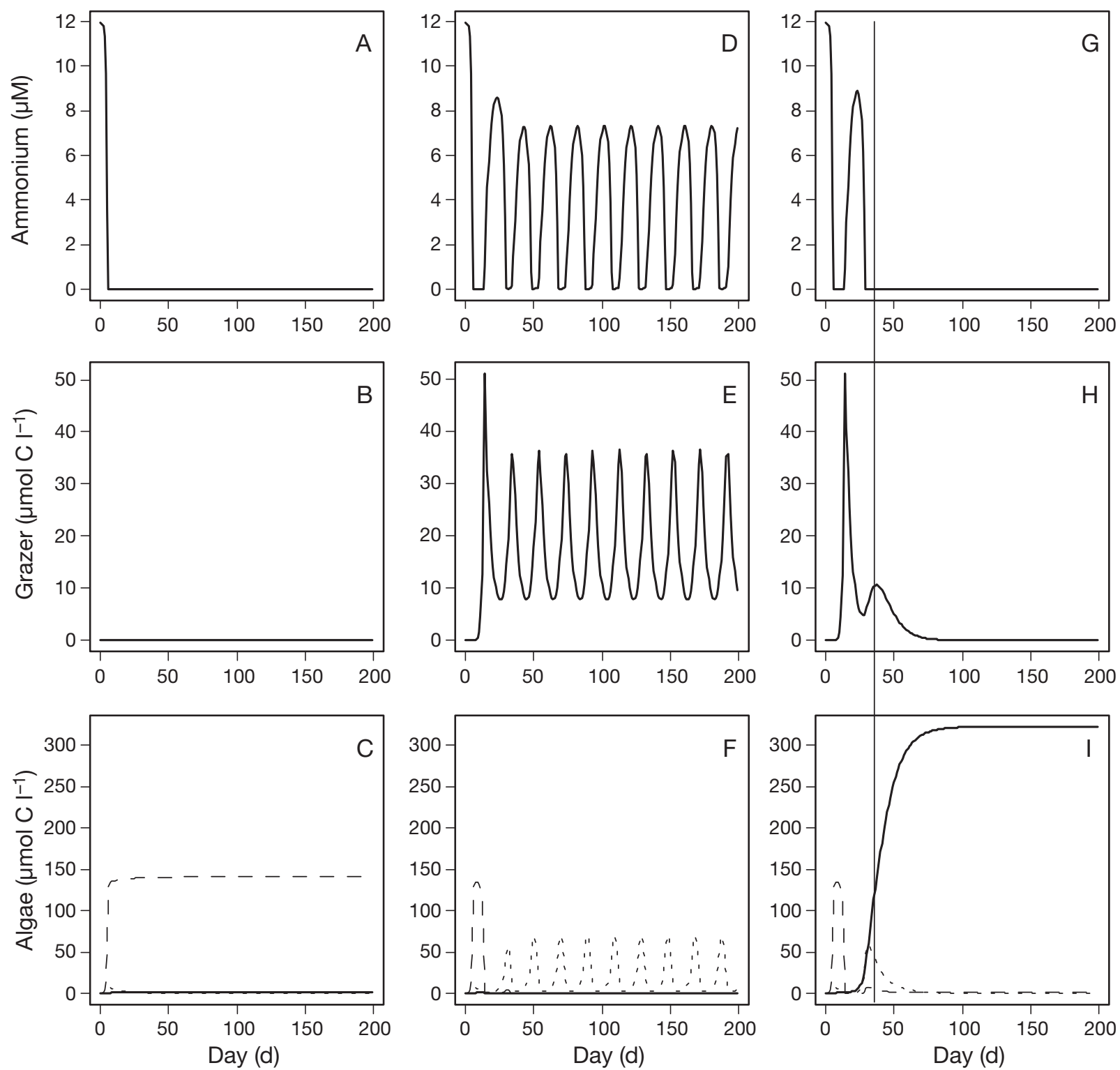

Fig. 3. Three time-course simulations: $(A, B, C)$ without a grazer, $(D, E, F)$ with a grazer where the maximum grazing rate on $A u$ reoumbra lagunensis is $30 \%\left(1.08 \mathrm{~d}^{-1}\right)$ of that on Thalassiosira pseudonana, and $(\mathrm{G}, \mathrm{H}, \mathrm{I})$ with a grazer where the maximum grazing rate on A. lagunensis is $10 \%\left(0.36 \mathrm{~d}^{-1}\right)$ of that on $T$. pseudonana. All other model parameters were set at their base values (see Supplement 1 at www.int-res.com/articles/suppl/m447p031_supp.pdf), including the dilution rate $\left(\delta=0.1 \mathrm{~d}^{-1}\right)$ and the inflowing ammonium $\left(N_{\text {in }}=12 \mu \mathrm{M}\right)$. In Panels C, F, and I, algal species are A. lagunensis (solid line), T. pseudonana (long-dashed line), and T. weissflogii (short-dashed line). The solid vertical line in Panels $\mathrm{G}, \mathrm{H}$, and I is presented to provide easy comparison among the panels in the region of brown tide bloom formation

3 preceding blooms of T.w. and 3 associated peaks in grazer abundance prior to the onset of the brown tide bloom, and that bloom did not begin until approximately Day 100 (results not shown).

The transition between stable diatom oscillations and the onset of a monospecific brown tide bloom occurred rather abruptly with decreasing grazing rates on A.l. (Fig. 4). A.l. blooms did not occur at maximum grazing rates on A.l. $>0.78 \mathrm{~d}^{-1}$ and, once formed, were continuous and monospecific at maximum grazing rates $<0.75 \mathrm{~d}^{-1}$ (Fig. 4C). A notable aspect of the modeled brown tide blooms was their high carbonbased biomass relative to blooms of the diatom species (Fig. 3F,I). The A.l. blooms reached carbon biomass levels of $>300 \mu \mathrm{mol} \mathrm{C} \mathrm{^{-1 }}$ at a total nitrogen concentration of $12 \mu \mathrm{M}$, while the pre-blooms of T.p. and T.w. reached values of only 60 to $130 \mu \mathrm{mol} \mathrm{Cl}^{-1}$ at the same total nitrogen concentration. 

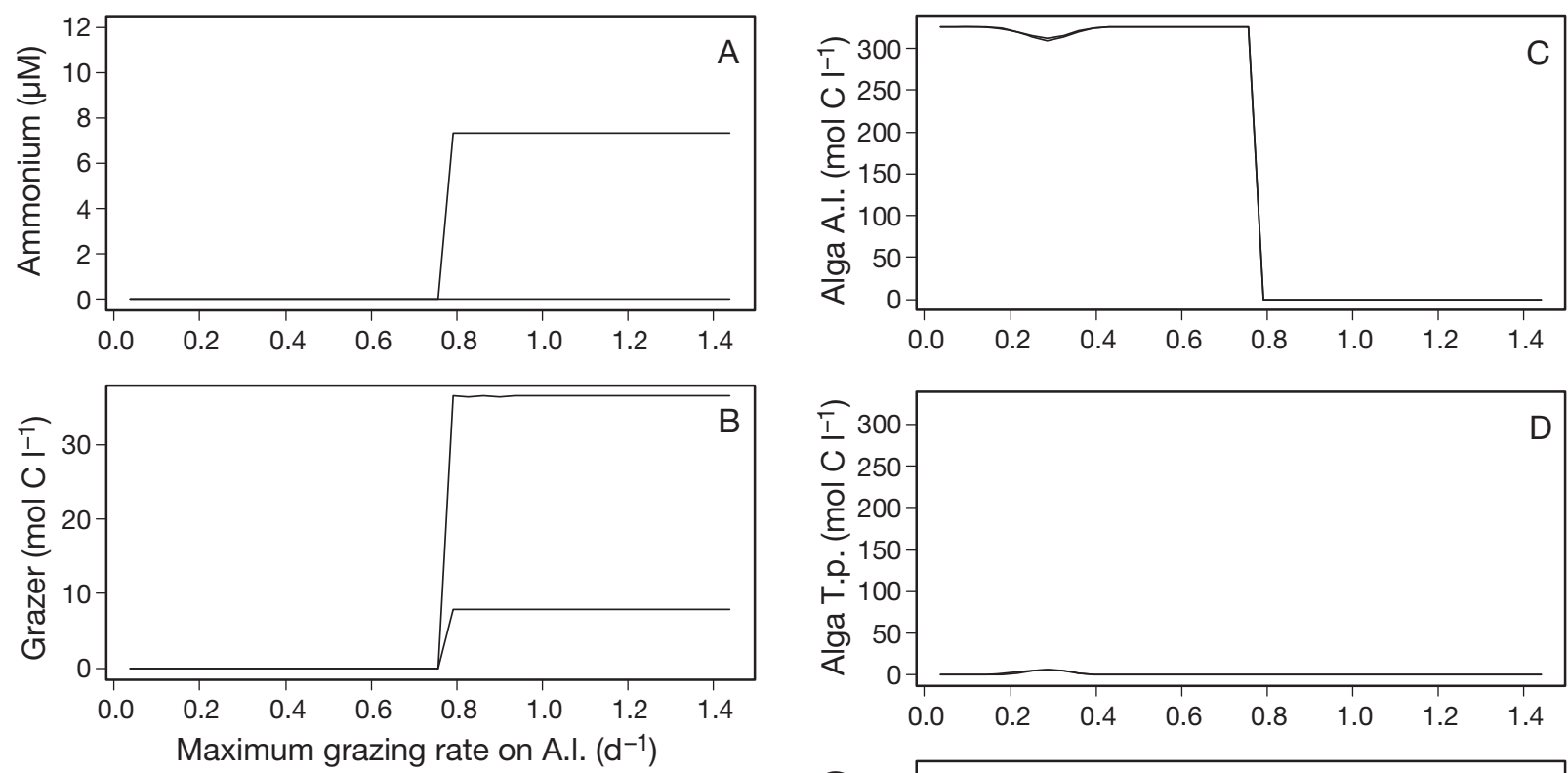

Fig. 4. Bifurcation diagram across maximum grazing rates on Aureoumbra lagunensis, showing stable long-term dynamics (computed from extended model runs, Days 1000 to 1500). Within that long-term period (500 d window), model dynamics either achieved a steady state (single response line) or stable oscillations (2 lines showing the upper and lower bounds). All other model parameters are the same as in Fig. 3. Algal species are A. lagunensis (A.1.), Thalassiosira pseudonana (T.p.), and T. weissflogii (T.w.)

We observed the need for a grazing threshold in our NPZ model. Without a grazing threshold, the model predicted successive peaks of T.p. abundance every $40 \mathrm{~d}$, with offset peaks for nutrients and the grazer (Fig. 5A to C). However, with a grazing threshold of $2 \mu \mathrm{mol} \mathrm{C} \mathrm{^{-1 }}$, the model still predicted an initial peak in T.p., but this was followed by multiple near simultaneous peaks in T.w. and T.p. abundance, with the peak heights separated by only $17 \mathrm{~d}$ (Fig. 5D-F). A log-scale plot of the data revealed the reason for the large difference in the 2 model runs. In the former case, the lack of a grazing threshold allowed the algae to be grazed down to very low levels which took long periods of growth for the algal populations to recover once the grazer population decreased and the grazing pressure subsided. These oscillations spanned 9 orders of magnitude in algal carbon for T.p., and, at the minimum in these oscillations, T.p. carbon biomass was only $8 \times 10^{-8} \mu \mathrm{mol} \mathrm{Cl} l^{-1}$ or only $1.3 \times 10^{-3} \mathrm{cells} \mathrm{ml}^{-1}$ based on a mean cell volume of $45 \mathrm{fl}$ (Sunda \& Hardison 2007). To avoid such unrealistically low cell densi-

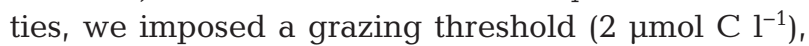
which reduced the maximum oscillation in T.p. abundance to only $\sim 1000$-fold so that the period between

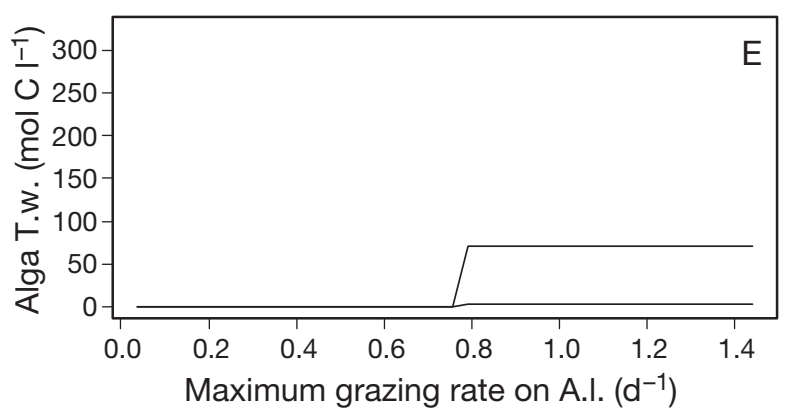

successive blooms was much shorter (Fig. 5F). The same grazing threshold was used in all of our NPZ models, with the exception of those shown in Fig. 5A to $\mathrm{C}$, where the threshold was deliberately omitted to show its effect as discussed above.

\section{Bottom-up effects}

The dynamics of our plankton models were also influenced by the residence time of the water in the flow-through system (and its inverse, the dilution rate) (Fig. 6). In our model runs, brown tide blooms occurred only at low dilution rates $\left(<0.22 \mathrm{~d}^{-1}\right)$ and continuous, monospecific blooms occurred only at dilution rates between 0.03 and $0.22 \mathrm{~d}^{-1}$ (Fig. 7). At intermediate dilution rates $\left(0.22\right.$ to $\left.0.28 \mathrm{~d}^{-1}\right)$, the model predicted stable oscillations among nutrients, T.w., and grazers, and, at higher dilution rates $\left(0.28\right.$ to $\left.0.44 \mathrm{~d}^{-1}\right)$, the model predicted successive cooccurring peaks in T.w. and T.p. populations (Figs. 6 \& 7). Finally, successive monospecific algal blooms of T.p. occurred at the highest dilutions rates. Within the region of stable brown tide blooms, the intensity 

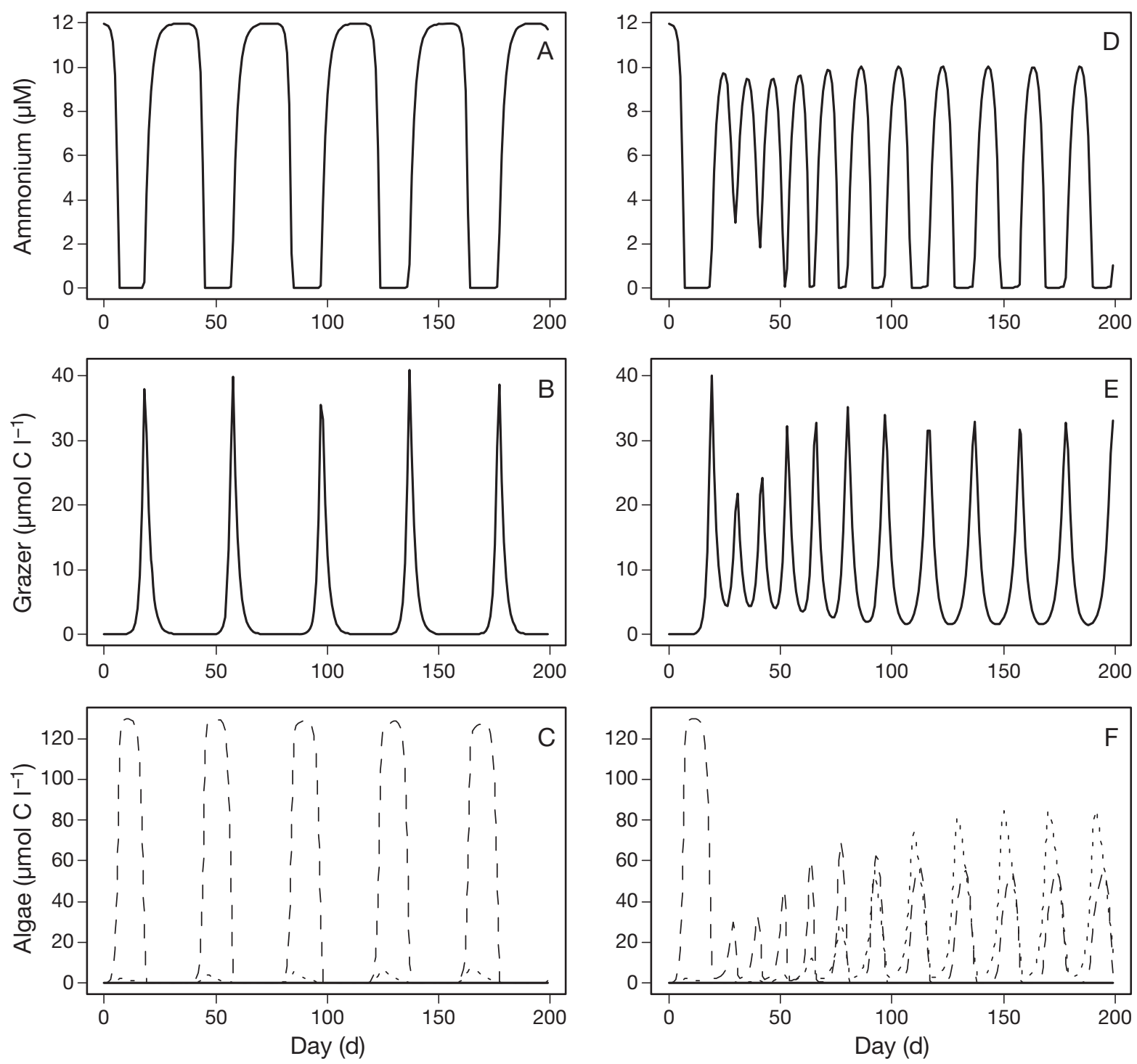

Fig. 5. Two time-course simulations at a dilution rate $(\delta)$ of $0.35 \mathrm{~d}^{-1}:(\mathrm{A}, \mathrm{B}, \mathrm{C})$ without a grazing threshold and $(\mathrm{D}, \mathrm{E}, \mathrm{F})$ with our

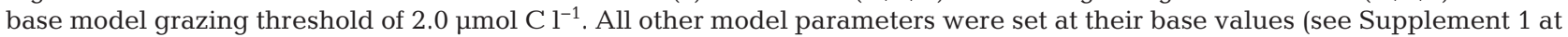
www.int-res.com/articles/suppl/m447p031_supp.pdf), including maximum grazing rate on A.l. $\left(g_{\max , 1}=0.72 \mathrm{~d}^{-1}\right)$ and inflowing ammonium $\left(N_{\text {in }}=12 \mu \mathrm{M}\right)$. In Panels $C$ and F, the algal species are Aureoumbra lagunensis (A.l., solid line), Thalassiosira pseudonana (T.p., long-dashed line), and T. weissflogii (T.w., short-dashed line)

of the bloom in terms of algal carbon biomass increased with decreasing dilution rate down to a critical value $\left(0.03 \mathrm{~d}^{-1}\right)$, at which point there was an abrupt transition to a pattern of stable oscillations among ammonium, A.l. biomass, and grazer populations, similar to those observed with the diatoms at higher dilution rates (Fig. 7). The impact of dilution rate was examined for a fixed maximum grazing rate on A.l. of $0.72 \mathrm{~d}^{-1}$, and the brown tide oscillations at very low dilution rates disappear at lower maximum grazing rates and are replaced by a continuous monospecific A.l. bloom (data not shown).
Increasing nutrient concentrations in the inflowing water also affected bloom dynamics. It is well known that increasing nutrient inputs increase the density of algal blooms, and this result is clearly seen in our models (Fig. 8), where a 9-fold increase in nutrient concentration increased the final algal carbon biomass of the brown tide bloom by 9-fold (Fig. 8C,F). But surprisingly, although an increase in nutrients increased the severity of the brown tide bloom, it also increased the period required for bloom onset by about 4 -fold. During that initial pre-bloom 

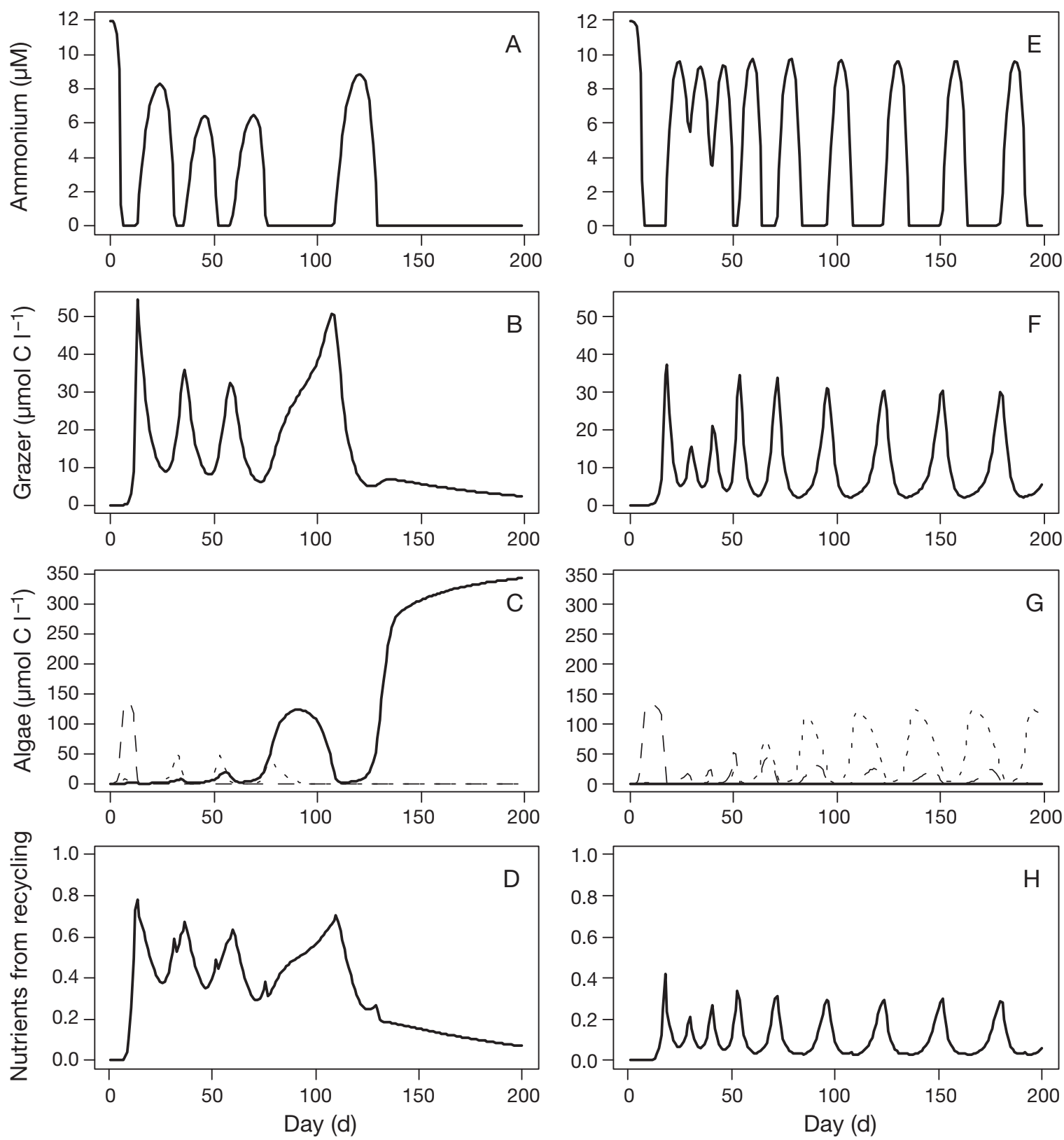

Fig. 6. Two time-course simulations: $(\mathrm{A}, \mathrm{B}, \mathrm{C}, \mathrm{D})$ with dilution rate $\delta=0.05 \mathrm{~d}^{-1}$ and $(\mathrm{E}, \mathrm{F}, \mathrm{G}, \mathrm{H})$ with $\delta=0.30 \mathrm{~d}^{-1}$. All other model parameters were set at their base values (see Supplement 1 at www.int-res.com/articles/suppl/m447p031_supp.pdf), including maximum grazing rate on Aureoumbra lagunensis (A.l., $\left.g_{\text {max }, 1}=0.72 \mathrm{~d}^{-1}\right)$ and inflowing ammonium $\left(N_{\mathrm{in}}=12 \mu \mathrm{M}\right)$. In Panels $\mathrm{C}$ and $\mathrm{G}$, the algal species are A.l. (solid line), Thalassiosira pseudonana (T.p., long-dashed line), and T. weissflogii (T.w., short-dashed line). The fraction of the total nitrogen input from recycled ammonium is given in Panels D and $\mathrm{H}$

period, there was an initial bloom of T.p. (which always occurs), followed by 4 separate pre-blooms of T.w. and associated peaks in grazer abundance (Fig 8F). Thus, while the relationship between nutrient concentration and bloom density may be straightforward, that between nutrient concentration and overall pre-bloom ecosystem dynamics can be quite complex.

\section{DISCUSSION}

Our modeling effort was undertaken to test the positive feedback hypothesis of Sunda et al. (2006) for the initiation and persistence of certain EDABs, such as those of the brown tide species Aureoumbra lagunensis and Aureococcus anophagefferens. In this conceptual model, harmful blooms were hypoth- 

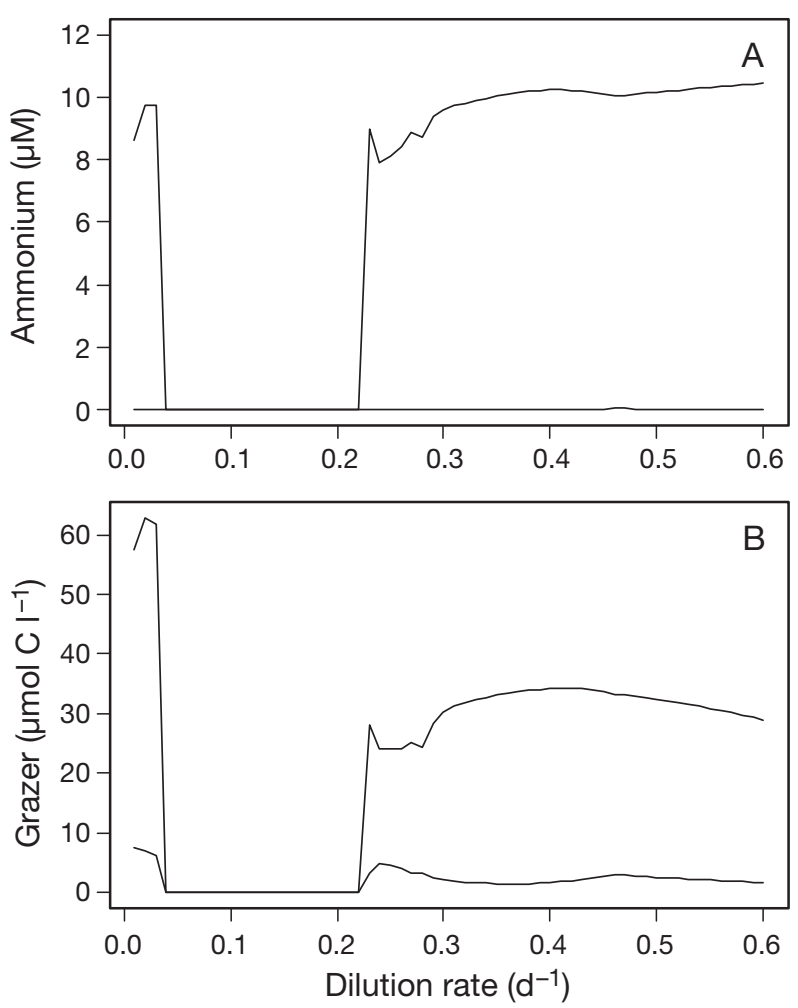

Fig. 7. Bifurcation diagram across dilution rates, showing stable long-term dynamics (computed from extended model runs, Days 1000 to 1500). Within that long-term period (500 d window), model dynamics either achieved a steady state (single response line) or stable oscillations (2 lines showing the upper and lower bounds). All other model parameters were the same as in Fig. 6. Algal species are Aureoumbra lagunensis (A.l.), Thalassiosira pseudonana (T.p.), and T. weissflogii (T.w.)

esized to result from complex interactions between bottom-up control by nutrients, top-down control by grazers, and positive feedbacks between the 2 control factors involving grazer-mediated nutrient recycling. Sunda et al. (2006) also proposed that A.l. and other EDAB algae are low-nutrient-adapted species which are poorly grazed by zooplankton and benthic grazers. Subsequent research with A.l. and 2 other EDAB species (the Long Island green tide species Nannochloris atomus and Nannochloropsis gaditana) indicated that these algae are indeed low-nutrientadapted ( $K$-selected) species (Sunda \& Hardison 2007, 2010).

It was further proposed that EDAB events required high inputs of utilizable nutrients, which would initially stimulate the growth of diatoms or other high-
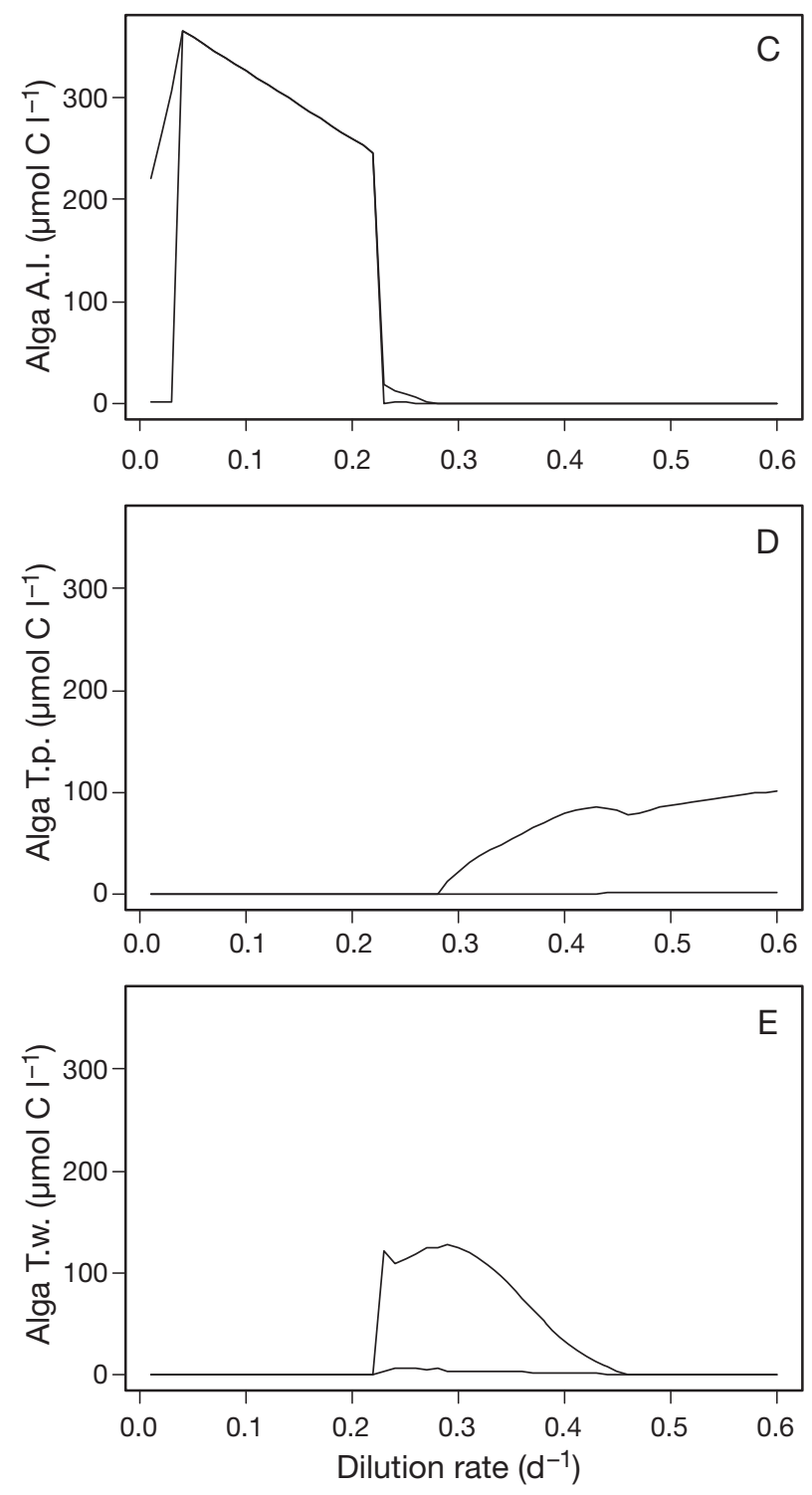

nutrient-adapted species (Sunda et al. 2006). Sunda et al. (2006) hypothesized that the pre-bloom of such r-selected species would draw down nutrients to low concentrations, setting the stage for a competitive switch to the EDAB species, which is better adapted to grow at low-nutrient concentrations (Fig. 2A). Indeed in our current simulations, 1 or more preblooms of high-nutrient (r-selected) diatom species preceded every A.l. bloom, and was a prerequisite for brown tide bloom formation (Figs. 3I, 6C \& 8C,F). The diatom pre-bloom(s) drew the ammonium concentrations down to very low concentrations $(0.008$ to $0.0022 \mu \mathrm{M})$, which severely restricted the growth of the algae and placed A.l. at a competitive growth advantage with co-occurring populations of T.w. (Figs. 2A, 3I, 6C \& 8C,F). Indeed, pre-blooms of 

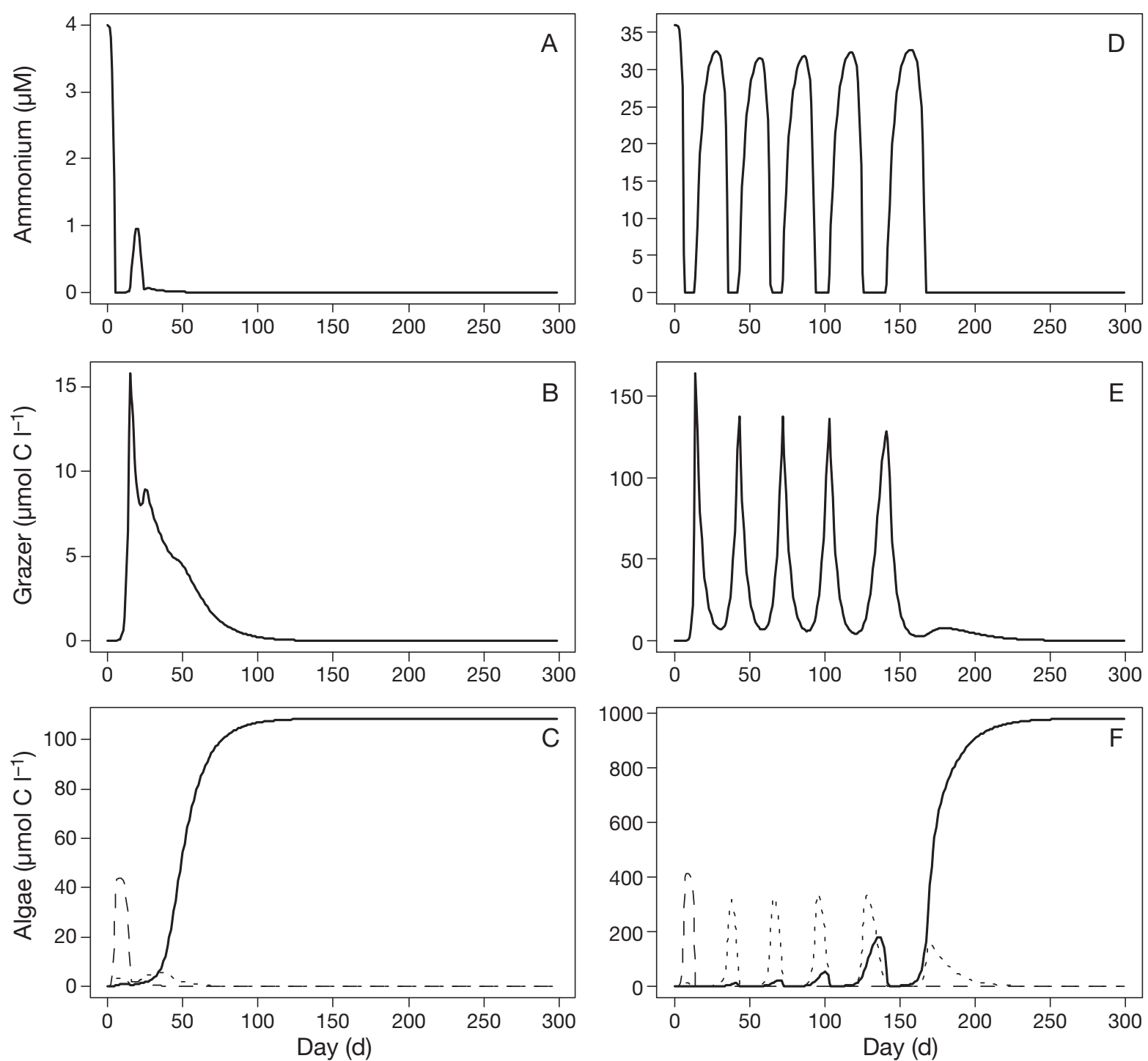

Fig. 8. Two time-course simulations: $(\mathrm{A}, \mathrm{B}, \mathrm{C})$ with nutrient input $N_{\mathrm{in}}=4 \mu \mathrm{M}$ and $(\mathrm{D}, \mathrm{E}, \mathrm{F})$ with $N_{\mathrm{in}}=36 \mu \mathrm{M}$. All other model parameters were set at their base values (see Supplement 1 at www.int-res.com/articles/suppl/m447p031_supp.pdf), including maximum grazing rate on Aureoumbra lagunensis (A.l., $\left.0.72 \mathrm{~d}^{-1}\right)$ and dilution rate $\left(0.1 \mathrm{~d}^{-1}\right)$. The $y$-axis scales are 9 -fold greater for simulations with $N_{\text {in }}=36 \mu \mathrm{M}$. In Panels C and F, the algal species are A.l. (solid line), Thalassiosira pseudonana (T.p., longdashed line), and T. weissflogii (T.w., short-dashed line)

diatoms which drew available nutrients to low concentrations have been observed in most EDAB events for which such data are available, including brown tide blooms of Aureococcus anophagefferens in coastal lagoons of Long Island, New York (Gobler \& Sanudo-Wilhelmy 2001, Sunda et al. 2006) and the massive monospecific bloom of Chrysochromulina polylepis that occurred in coastal waters of Scandanavia in 1988 (Maestrini \& Graneli 1991). However, pre-blooms were not apparent before the 1990 A.l. bloom in Laguna Madre because high salinities linked to drought (55 to $70 \mathrm{psu}$ ) may have inhibited the growth of diatoms, but had little effect on the growth of the halotolerant A.l. (Buskey et al. 1998, 2001).

Sunda et al. (2006) proposed that a combination of an ability to grow competitively at low concentrations of limiting nutrients and low grazing mortality rates would allow EDAB species to proliferate relative to populations of the competing phytoplankton. The increased abundance of poorly grazed EDAB species would further decrease grazing rates and thereby decrease grazer populations and grazermediated nutrient recycling. The decreased input of recycled nutrients would, in turn, decrease nutrient concentrations and thereby further favor the growth 
of the EDAB species. Sunda et al. (2006) hypothesized that these interactions constituted a positive feedback that would promote the formation of monospecific EDAB events, with co-occurring low concentrations of nutrients, algal grazers, and competing phytoplankton. All of these predictions are verified in our current model simulations (Figs. 3G-I, 6A-D \& $8 \mathrm{~A}-\mathrm{F})$.

Our model simulations reveal another positive feedback that promotes the formation of brown tide blooms. The $\mathrm{N}: \mathrm{C}$ ratios in $\mathrm{N}$-limited A.l. cells are up to 5 -fold lower than in $\mathrm{N}$-sufficient cells, and are $>2$-fold lower than in N-limited diatoms (Fig. 2A). Thus, as the algae become N-limited during the formation of the brown tide bloom, the $\mathrm{N}: \mathrm{C}$ ratio in A.l. cells decreases substantially, which decreases the excess metabolic nitrogen available for excretion by zooplankton consuming these algae. The low N:C ratio of assimilated food ultimately decreases the nitrogen available for grazer growth for a given carbon ingestion rate, and, at a sufficiently low $\mathrm{N}$ :C ratio in the consumed algae, the grazer growth rate shifts from carbon to nitrogen limitation, with a concomitant decrease in the growth rate of the grazer. Both effects decrease grazing-linked nutrient recycling, thereby decreasing nutrient concentrations and further decreasing cellular $\mathrm{N}: \mathrm{C}$ ratios in the consumed algae. Such positive feedback effects linked to algal nutrient:carbon stoichiometry have been previously described, at least in terms of their effect on the palatability of algal prey and adverse effects on the growth rate of grazer species (Irigoien et al. 2005, Mitra \& Flynn 2006). Other EDAB species, such as the green tide species Nannochloropsis gaditana and Nannochloris atomus, have similar unusually low $\mathrm{N}: \mathrm{C}$ ratios under N-limitation of growth rate (Sunda \& Hardison 2010), and these and other similar EDAB species should also be subject to positive feedback bloom effects due to these low stoichiometric ratios.

Many algal species increase their grazing defenses (such as toxin levels or cell wall thickness) under nutrient limitation, providing an additional source of positive feedback during the formation of harmful blooms (Mitra \& Flynn 2006, Sunda et al. 2006). Although such increases in grazing defenses under nutrient limitation can promote EDAB events, they were not included in the present NPZ EDAB model.

Sunda et al. (2006) noted that because of the positive feedback, once the EDAB species dominated the phytoplankton community, the bloom would persist, provided that critical factors such as dilution rate, nutrient inputs, or temperature did not change, or the bloom was not terminated by infectious agents such as viruses. This persistence is seen in virtually all of our brown tide simulations. Such bloom persistence was observed in the Texas (USA) brown tide bloom of A.l. that occurred initially in the Laguna Madre in 1990 (Buskey et al. 2001). As in our simulations, the bloom formation was accompanied by a sharp drop in the concentration of ammonium (Buskey et al. 1996) and in the abundance of mesozooplankton, microzooplankton, and competing species of phytoplankton (Buskey \& Stockwell 1993). The average $\mathrm{C}: \mathrm{N}$ ratio measured during the bloom was 28 (4 times the nutrient-sufficient value of 7; Fig. 2B), which indicated that A.l. growth was nitrogen-limited (DeYoe \& Suttle 1994). The bloom persisted for almost $8 \mathrm{yr}$, and was the longest continuous algal bloom on record. It was terminated by heavy rains in the fall of 1997, which decreased salinity and increased nutrient inputs and nutrient concentrations, and caused successive blooms of diatoms and cyanobacteria, followed by a new bloom of brown tide (Buskey et al. 2001).

One of the unexpected outcomes of our plankton dynamics simulations was the much higher carbon biomass of the brown tide blooms relative to those of the 2 diatoms. At an ammonium input concentration of $12 \mu \mathrm{M}$, the continuous brown tide blooms reached algal biomass levels of 250 to $350 \mu \mathrm{mol} \mathrm{C} \mathrm{l}^{-1}$ depending on the water dilution rate (Fig. $7 \mathrm{C}$ ), whereas the diatoms reached biomass levels that were much lower (50 to $120 \mu \mathrm{mol} \mathrm{C}{ }^{-1}$ ). The much higher algal carbon concentrations were related to the onset of $\mathrm{N}$-limitation during the blooms, and the progressive increase in $\mathrm{C}: \mathrm{N}$ ratios with increasing degree of $\mathrm{N}$-limitation. The higher algal carbon concentrations were related to the fact that the maximum C:N molar ratio under severe growth rate limitation in A.l. (32) was 2.3- to 2.8-fold higher than observed in the 2 diatoms (Fig. 2B). Another factor was that during fully developed brown tide blooms in our simulations, the degree of N-limitation of algal cells was generally higher than that observed in the much shorter duration diatom blooms because of the lower grazer concentrations and grazer-mediated inputs of recycled nutrients during the brown tide blooms (Fig. 6B,D). Because of the loss of grazers and competing phytoplankton, the persistent brown tide blooms resembled a monospecific continuous culture of A.l., in which the specific growth rate of the algae equaled the dilution rate of the system. Thus, as the dilution rate decreased, there was a progressive decrease in the $\mathrm{N}$-limited growth rate, and a related increase in the $\mathrm{C}: \mathrm{N}$ ratio (and a decrease in $\mathrm{N}: \mathrm{C}$ ratio) of the brown tide bloom, down to very low dilution 
rates $\left(<0.03 \mathrm{~d}^{-1}\right)$, below which stable oscillations in brown tide, nutrients, and grazers occurred (Fig. 7C).

Another surprising feature of the model was the sensitivity of the simulated brown tide bloom to small variations in maximum grazing rate on A.l. (Fig. 4C) and the dilution rate of the system (Fig. $7 \mathrm{C}$ ). Although, the conceptual model of Sunda et al. (2006) had predicted that decreasing grazing rates on EDAB species and decreasing system dilution rate would both favor EDAB events, our quantitative model shed light on just how sharp the transitions were between the occurrence of successive diatom blooms and the onset of brown tide blooms with decreases in these 2 parameters. We attribute these sharp transitions to the positive feedbacks that occur during brown tide bloom initiation (e.g. Fig. 3I). Such bifurcations in dynamics have been observed in other experimental and model NPZ systems (Fussmann et al. 2000). As the dilution rate increased from 0.22 to $0.23 \mathrm{~d}^{-1}$ brown tide blooms disappeared and were replaced by repeating blooms of diatoms, first of T.w. by itself, then T.w. and T.p. together, and finally T.p. alone at the highest dilution rate (Fig. $7 \mathrm{C}$ to E). Thus, the occurrence of brown tide blooms and the dominant algal bloom species were highly dependent on the residence time of the water in the system, with long residence times favoring brown tide blooms and short residence times favoring blooms of the fastgrowing diatom T.p. The Laguna Madre, where the record A.l. bloom occurred, has minimal freshwater inputs and long residence times (Buskey et al. 2001). Such extended residence times favor the formation of blooms of A.l. and other EDAB species by increasing the importance of nutrient recycling to the overall supply of limiting nutrients, as seen in our current simulations (Fig. 6D,H). In further support of this effect, the Long Island brown tide blooms of Aureococcus anophagefferens during the late 1980s and 1990s were found to occur preferentially in dry years, when water residence times were high (Gobler \& Sanudo-Wilhelmy 2001).

Another interesting finding from our simulations was the effect of nutrient concentration in the inflowing water. Increasing the ammonium concentration in the inflowing water increased the intensity of the brown tide bloom as expected (Fig. 8C,F). However, the increase in input concentration also delayed the occurrence of the brown tide bloom, and increased the number of pre-blooms of the large diatom T.w. and co-occurring oscillations in concentrations of ammonium and algal grazers. Thus, increasing the nutrient inputs delayed the brown tide bloom and made it somewhat less likely to occur; however, when it did occur, its intensity (i.e. biomass) was much greater. Such blooms would likely be accompanied by more severe negative impacts on the ecosystem, such as the disruption of the food web and loss of sea grass beds (Buskey \& Stockwell 1993, Dunton 1994, Onuf 1996). The effect of increased nutrients in promoting additional pre-blooms of T.w. and delaying the onset of the brown tide bloom is related to the resultant higher nutrient concentrations and lower proportion of the time in which low nutrient concentrations limited algal growth rates, which favored the growth of the r-selected diatoms (Figs. 2A \& 7A,D).

The above model predictions, however, may underestimate the adverse impact of increased anthropogenic nutrient inputs from agricultural runoff, municipal waste, or fossil fuel burning. These inputs increase concentrations of available nitrogen and phosphorus, but do not increase silicon levels. Silicon is required for the growth of diatoms, but not for that of other species, and, thus, anthropogenic nutrient pollution tends to favor blooms of non-diatom species over those of diatoms (Conley et al. 1993). If this behavior had been factored into our model, increased anthropogenic inputs of $\mathrm{N}$ and $\mathrm{P}$ would not only have increased the severity of brown tide blooms, but also would have increased their likelihood, and decreased the number and magnitude of diatom pre-blooms.

For simplicity in our model, we varied relative grazing on the 3 algal species by decreasing the maximum grazing rate $\left(g_{\max , i}\right)$ for T.w. and A.l., but assumed that the half-saturation grazing values $\left(K_{\mathrm{z}}\right)$ were the same for each species. However, the maximum grazing rates and the half-saturation values for different algal prey often vary together with increased algal defenses. To examine this effect, we repeated the simulations that were conducted at 2 dilution rates (Fig. 6), but modified the model so that the half-saturation grazing value of each algal species varied by the same relative amount as the inverse of the maximum grazing rate (see Supplement 3 at www.int-res.com/articles/suppl/m447p031_ supp.pdf). At the low dilution rate $\left(\delta=0.05 \mathrm{~d}^{-1}\right)$, a combined 5 -fold decrease in the maximum grazing rate and 5-fold increase in $K_{\mathrm{z}}$ for A.l. caused the brown tide bloom to initiate much more quickly (after ca. 25 d), with a single pre-bloom of T.p. and only a small bloom of T.w., which soon subsided due to preferential grazing (Supplement 3; Fig. S2C). By contrast, if only the maximum grazing rate was decreased, the brown tide bloom took much longer to initiate (ca. 125 d) and was preceded by several preblooms of the diatom T.w. (Fig. 6C). At the higher 
dilution rate $\left(\delta=0.3 \mathrm{~d}^{-1}\right)$, varying both grazing curve parameters resulted in a brown tide bloom (Supplement 3, Fig. S2F), whereas a similar bloom was not seen if only the maximum grazing rate was varied (Fig. 6G). Thus, our results where we varied only maximum grazing rates may underestimate the strength of the positive feedback caused by low grazing mortality of the EDAB species.

Another simplification in the model is that it considered only 1 form (ammonium) of the limiting nutrient nitrogen and did not consider other important utilizable forms such as nitrate. Nitrate is often the major form of biologically available nitrogen derived from external sources such as rivers, ground water, atmospheric deposition, and upwelling; and, in systems where nitrogen inputs are primarily in this form, initial blooms of diatoms would be even more selected for than in the current model, as available evidence suggests that A.l. cannot utilize this substrate (DeYoe \& Suttle 1994). However, once nitrate is assimilated by algae, it is reduced to the amine oxidation state and is recycled by grazer-mediated processes in the form of ammonium or various organic amines (e.g. urea and amino acids). These reduced, recycled forms of nitrogen would permit the growth of A.l. (Muhlstein \& Villareal 2007), but there may need to be co-occurring algal species to utilize incoming nitrate, along with the presence of grazers to recycle the algal nitrogen into ammonium for the bloom to persist. However, to date, the nitrogen preferences of only one A.l. strain have been examined (DeYoe \& Suttle 1994), so it is quite possible that other A.l. strains may utilize nitrate and fulfill the role of co-occurring nitrate-utilizing species.

If A.l. cannot use nitrate, it would be atypical, as the overwhelming majority of algal species can utilize this substrate (Antia et al. 1975, DeYoe \& Suttle 1994), including the Northeast United States brown tide species Aureococcus anophagefferens (Gobler \& Sunda 2012) and the 2 Long Island green tide species Nannochloris atomus (Sunda \& Guillard 1976) and Nannochloropsis gaditana (https://ncma.bigelow.org). For both of these green tide species, measured relationships between specific growth rate and ammonium concentration and between specific growth rate and cellular $\mathrm{N}: \mathrm{C}$ ratio are similar to those for A.l., and, like A.l., these species have maximum specific growth rates at $20^{\circ} \mathrm{C}\left(0.71\right.$ and $0.59 \mathrm{~d}^{-1}$, respectively) that are lower than those of the diatoms T.p. and T.w. (1.45 and $0.87 \mathrm{~d}^{-1}$, respectively) (Sunda \& Hardison 2010). Thus, if we were to replace A.l. with either of these 2 EDAB species, the overall model results would be similar to those observed for A.l. with regard to the role of positive feedbacks in promoting the formation and persistence of EDAB events. For these species, and likely most other EDAB species, whether the external inputs of nitrogen are primarily in the form of nitrate or ammonium (or organic nitrogen substrates) may have less of an effect on bloom dynamics than for species incapable of utilizing nitrate.

\section{CONCLUSIONS}

Our NPZ model results support the positive feedback hypothesis for the formation of certain EDABs (Mitra \& Flynn 2006, Sunda et al. 2006). It shows that such blooms are unlikely to result merely from the growth stimulation of EDAB species in response to added nutrients, but rather from complex interactions involving competition among algal species for available nutrients, low grazing mortality rates on the EDAB species, and positive feedbacks linked to grazer-mediated nutrient cycling and nutrient limitation. Laboratory data show that EDAB species, such as Aureoumbra lagunensis (A.1.), are low-nutrientadapted species that compete well at low-nutrient levels, but compete poorly for growth at high-nutrient concentrations (Sunda \& Hardison 2010). In our model, inputs of nutrients (ammonium) initially favored the growth of high-nutrient-adapted species (the diatoms Thalassiosira pseudonana [T.p.] and T. weissflogii [T.w.]) which drew down nutrients to low levels. The resulting low-nutrient concentrations preferentially favored the growth of A.l. relative to that of the large diatom (T.w.) and led to similar growth rates for A.l. and T.p. This more favorable competitive growth, along with A.l.'s much lower grazing mortality rates, allowed the brown tide to proliferate. As the brown tide numbers increased relative to those of the diatoms, grazer-mediated recycling of nutrients decreased, which further decreased nutrient concentrations and further favored the growth rate of the brown tide species relative to the growth rates of the diatoms. This chain of events represented a positive feedback that progressively lowered nutrient concentrations and thereby promoted the accumulation of the low-nutrient-adapted brown tide species.

In the above scenario, the onset of nutrient (nitrogen) limitation lowered algal N:C ratios, which provided an additional nutrient-linked positive feedback. This occurred because the lower $\mathrm{N}$ : $\mathrm{C}$ ratios in ingested algae progressively lowered nitrogenexcretion rates by the zooplankton, and thereby further lowered available nitrogen concentrations in the 
water and increased nitrogen limitation of the algae. In our model, both of the positive feedback mechanisms promoted the formation of a persistent brown tide bloom that was associated with low concentrations of available nitrogen, competing phytoplankton, and zooplankton grazers. Although our model was specifically applied to the brown tide species A.l., its behavior should also apply to other EDAB species, which share many of the same attributes as A.l. (growth adaptation to low nutrients, low grazing rates due to robust defenses, and low $\mathrm{N}$ :C ratios under low available nitrogen concentrations). These algae include the brown tide species Aureococcus anophagefferens, the green tide species Nannochloris atomus and Nannochloropsis gaditana, toxic bloom-forming prymnesiophytes (Chrysochromulina polylepis and Prymnesium parvum), and some toxicbloom-forming cyanobacteria (e.g. Nodularia spumigena), and toxic dinoflagellates (Sunda et al. 2006, Sunda \& Hardison 2010). We expect that as more is learned about growth and grazing characteristics, other harmful algal bloom species will be added to our list of EDAB species whose blooms are promoted by positive feedback interactions.

Acknowledgements. We thank Suzanne Strom and Diane Stoecker for useful information on grazing and growth of marine ciliates, and thank Wayne Litaker, Rance Hardison, and 2 anonymous reviewers for helpful comments on the manuscript. Views expressed are those of the authors and do not necessarily represent those of NOAA or any other government agency.

\section{LITERATURE CITED}

Antia NJ, Berland BR, Bonin DJ, Maestrini SY (1975) Comparative evaluation of certain organic and inorganic sources of nitrogen for phototrophic growth of marine microalgae. J Mar Biol Assoc UK 55:519-539

Bersano JGF, Buskey EJ, Villareal TA (2002) Viability of the Texas brown tide alga, Aureoumbra lagunensis, in fecal pellets of the copepod Acartia tonsa. Plankton Biol Ecol 49:88-92

> Buskey EJ (2008) How does eutrophication affect the role of grazers in harmful algal bloom dynamics? Harmful Algae 8:152-157

Buskey EJ, Hyatt CJ (1995) Effects of the Texas (USA) 'brown tide' alga on planktonic grazers. Mar Ecol Prog Ser 126:285-292

Buskey EJ, Stockwell DA (1993) Effects of a persistent 'brown tide' on zooplankton populations in the Laguna Madre of south Texas. In: Smayda TJ, Shimizu Y (eds) Toxic phytoplankton blooms in the sea. Elsevier, Amsterdam

Buskey EJ, Stewart S, Peterson J, Collumb C (1996) Current status and historical trends of brown tide and red tide phytoplankton blooms in the Corpus Christi Bay National Estuary Program study area. Texas Natural
Resource Conservation Commission, Austin, TX

Buskey EJ, Wysor B, Hyatt C (1998) The role of hypersalinity in the persistence of the Texas 'brown tide' in the Laguna Madre. J Plankton Res 20:1553-1565

> Buskey EJ, Liu HB, Collumb C, Bersano JGF (2001) The decline and recovery of a persistent Texas brown tide algal bloom in the Laguna Madre (Texas, USA). Estuaries 24:337-346

> Calbet A, Landry MR (2004) Phytoplankton growth, microzooplankton grazing, and carbon cycling in marine systems. Limnol Oceanogr 49:51-57

Caron DA, Goldman JC (1990) Protozoan nutrient regeneration. In: Capriulo GM (ed) Ecology of marine protozoa. Oxford University Press, New York, NY, p 283-306

> Charlson RJ, Lovelock JE, Andreae MO, Warren SG (1987) Oceanic phytoplankton, atmospheric sulfur, cloud albedo and climate. Nature 326:655-661

> Chen B, Liu H, Lau MTS (2010) Grazing and growth responses of a marine oligotrichous ciliate fed with two nanoplankton: Does food quality matter for micrograzers? Aquat Ecol 44:113-119

> Cloern JE (2001) Our evolving conceptual model of the coastal eutrophication problem. Mar Ecol Prog Ser 210: 223-253

Conley DJ, Schelske CL, Stoermer EF (1993) Modification of the biogeochemical cycle of silica with eutrophication. Mar Ecol Prog Ser 101:179-192

$>$ DeYoe HR, Suttle CA (1994) The inability of the Texas 'brown tide' alga to use nitrate and the role of nitrogen in the initiation of a persistent bloom of this organism. J Phycol 30:800-806

$>$ Droop MR (1968) Vitamin $B_{12}$ and marine ecology. IV. The kinetics of growth and inhibition in Monochrysis lutheri. J Mar Biol Assoc UK 48:689-733

$>$ Dugdale RC, Goering JJ (1967) Uptake of new and regenerated forms of nitrogen in primary productivity. Limnol Oceanogr 12:196-206

$>$ Dunton KH (1994) Seasonal growth and biomass of the subtropical seagrass Halodule wrightii in relation to continuous measurements of underwater irradiance. Mar Biol 120:479-489

> Dymond J, Lyle M (1985) Flux comparisons between sediments and sediment traps in the eastern tropical Pacific: implications for atmospheric $\mathrm{CO}_{2}$ variations during the Pleistocene. Limnol Oceanogr 30:699-712

Field CB, Behrenfeld MJ, Randerson JT, Falkowski P (1998) Primary production of the biosphere: integrating terrestrial and oceanic components. Science 281:237-240

Frost BW (1975) A threshold feeding behavior in Calanus pacificus. Limnol Oceanogr 20:263-266

Frost BW (1993) A modeling study of processes regulating plankton standing stock and production in the open subarctic Pacific Ocean. Prog Oceanogr 32:17-56

Fussmann GF, Heber G (2002) Food web complexity and chaotic dynamics. Ecol Lett 5:394-401

> Fussmann GF, Ellner SP, Shertzer KW, Hairston NG Jr (2000) Crossing the hopf bifurcation in a live predator-prey system. Science 290:1358-1360

Gentleman W, Leising A, Frost B, Strom S, Murray J (2003) Functional responses for zooplankton feeding on multiple resources: a review of assumptions and biological dynamics. Deep-Sea Res II 50:2847-2875

$>$ Gismervik I (2005) Numerical and functional responses of choreo- and oligotrich planktonic ciliates. Aquat Microb Ecol 40:163-173 
Glibert PM, Anderson DM, Gentien P, Graneli E, Sellner KG (2005) The global, complex phenomena of harmful algal blooms. Oceanography (Wash DC) 18:136-147

Gobler CJ, Sanudo-Wilhelmy SA (2001) Temporal variability of groundwater seepage and brown tide blooms in a Long Island embayment. Mar Ecol Prog Ser 217:299-309

Gobler CJ, Sunda WG (2012) Ecosystem disruptive algal blooms of the brown tide species Aureococcus anophagefferens and Aureoumbra lagunensis. Harmful Algae 14:36-45

Hansen PJ, Bjornsen PK, Hansen BW (1997) Zooplankton grazing and growth: scaling within $2-2,000-\mu \mathrm{m}$ body size range. Limnol Oceanogr 42:687-704

Harrison WG, Harris LR, Irwin BD (1996) The kinetics of nitrogen utilization in the oceanic mixed layer: nitrate and ammonium interactions at nanomolar concentrations. Limnol Oceanogr 41:16-32

- Hoagland P, Anderson DM, Kaoru Y, White AW (2002) The economic effects of harmful algal blooms in the United States: estimates, assessment issues, and information needs. Estuaries 25:819-837

Irigoien X, Flynn KJ, Harris RP (2005) Phytoplankton blooms: A 'loophole' in microzooplankton grazing impact? J Plankton Res 27:313-321

Kiørboe T (1993) Turbulence, phytoplankton cell size, and the structure of pelagic food webs. Adv Mar Biol 29:1-72

> Leising AW, Gentleman WC, Frost BW (2003) The threshold feeding response of microzooplankton within Pacific high-nitrate low-chlorophyll ecosystem models under steady and variable iron input. Deep-Sea Res II 50: 2877-2894

> Liu HB, Buskey EJ (2000) The exopolymer secretions (EPS) layer surrounding Aureoumbra lagunensis cells affects growth, grazing, and behavior of protozoa. Limnol Oceanogr 45:1187-1191

Maestrini SY, Graneli E (1991) Environmental conditions and ecophysiological mechanisms which led to the 1988 Chrysochromulina polylepis bloom: an hypothesis. Oceanol Acta 14:397-413

Martin JH (1990) Glacial-interglacial $\mathrm{CO}_{2}$ change: the iron hypothesis. Paleoceanography 5:1-13

Mitra A, Flynn K (2005) Predator-prey interactions: Is 'ecological stoichiometry' sufficient when good food goes bad? J Plankton Res 27:393-399

Mitra A, Flynn K (2006) Promotion of harmful algal blooms by zooplankton predatory activity. Biol Lett 2:194-197

Moore CM, Mills MM, Langlois R, Milne A, Achterberg EP, La Roche J, Geider RJ (2008) Relative influence of nitrogen and phosphorus availability on phytoplankton physiology and productivity in the oligotrophic sub-tropical North Atlantic Ocean. Limnol Oceanogr 53:291-305

Muhlstein HI, Villareal TA (2007) Organic and inorganic nutrient effects on growth rate-irradiance relationships in the Texas brown-tide alga Aureoumbra lagunensis (Pelagophyceae). J Phycol 43:1223-1226

> Onuf CP (1996) Seagrass responses to long-term light re-

Editorial responsibility: Katherine Richardson, Copenhagen, Denmark duction by brown tide in upper Laguna Madre, Texas: distribution and biomass patterns. Mar Ecol Prog Ser 138:219-231

Pierce RW, Turner JT (1992) Ecology of planktonic ciliates in marine food webs. Rev Aquat Sci 6:139-181

Redfield AC, Ketchum BH, Richards FA (1963) The influence of organisms on the composition of seawater. In: Hill MN (ed) The sea, Book 2. Wiley, New York, NY

Ryther JH (1969) Photosynthesis and fish production in the sea. Science 166:72-76

Ryther JH, Dunstan WM (1971) Nitrogen, phosphorus, and eutrophication in the coastal marine environment. Science 171:1008-1013

Sanders JG, Dibik SJ, D'Elia CF, Boynton WR (1987) Nutrient enrichment studies in a coastal plain estuary: changes in phytoplankton species composition. Can J Fish Aquat Sci 44:83-90

Sigman DM, Boyle EA (2000) Glacial/interglacial variations in atmospheric carbon dioxide. Nature 407:859-869

Sterner RW, Elser JJ (2002) Ecological stoichiometry: the biology of elements from molecules to the biosphere. Princeton University Press, Princeton, NJ

- Strom SL (1991) Growth and grazing rates of the herbivorous dinoflagellate Gymnodinium sp. from the open subarctic Pacific Ocean. Mar Ecol Prog Ser 78:103-113

Strom SL, Miller CB, Frost BW (2000) What sets the lower limit to phytoplankton stocks in high-nitrate, lowchlorophyll regions of the open ocean? Mar Ecol Prog Ser 193:19-31

Sunda WG, Guillard RRL (1976) The relationship between cupric ion activity and the toxicity of copper to phytoplankton. J Mar Res 34:511-529

Sunda WG, Hardison DR (2007) Ammonium uptake and growth limitation in marine phytoplankton. Limnol Oceanogr 52:2496-2506

Sunda WG, Hardison DR (2010) Evolutionary tradeoffs among nutrient acquisition, cell size, and grazing defense in marine phytoplankton promote ecosystem stability. Mar Ecol Prog Ser 401:63-76

Sunda WG, Graneli E, Gobler CJ (2006) Positive feedback and the development and persistence of ecosystem disruptive algal blooms. J Phycol 42:963-974

Sunda WG, Shertzer KW, Hardison DR (2009) Ammonium uptake and growth models in marine diatoms: Monod and Droop revisited. Mar Ecol Prog Ser 386:29-41

> Thingstad TF, Sakshaug E (1990) Control of phytoplankton growth in nutrient recycling ecosystems. Theory and terminology. Mar Ecol Prog Ser 63:261-272

Tian RC (2006) Toward standard parameterizations in marine biological modeling. Ecol Modell 193:363-386

> Verity PG (1985) Grazing, respiration, excretion, and growth rates of tintinnids. Limnol Oceanogr 30:1268-1282

- Ward LA, Montagna PA, Kalke RD, Buskey EJ (2000) Sublethal effects of Texas brown tide on Streblospio benedicti (Polychaeta) larvae. J Exp Mar Biol Ecol 248: $121-129$

Submitted: May 4, 2011; Accepted: November 6, 2011

Proofs received from author(s): January 24, 2012 